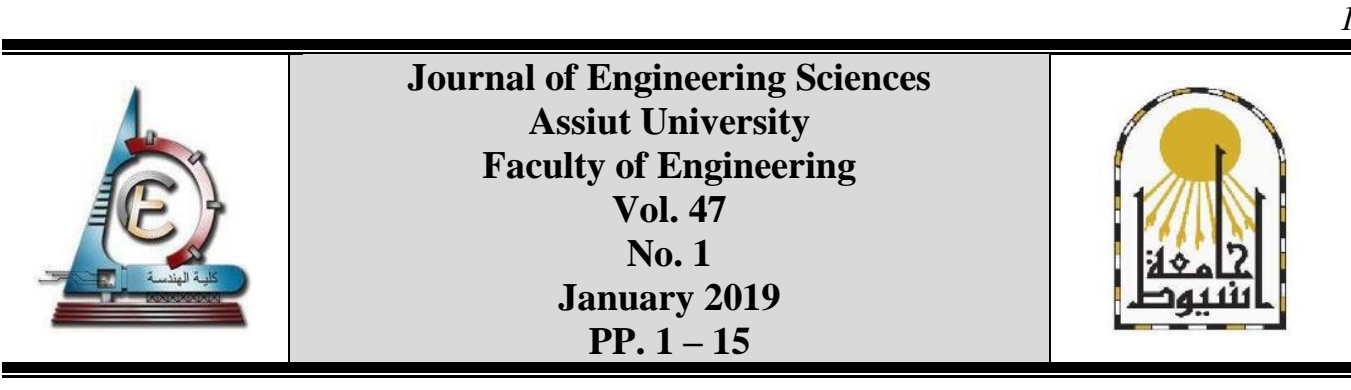

\title{
EFFICIENCY OF DIFFERENT STRENGTHENING TECHNIQUES ON SEISMIC PERFORMANCE OF R.C. FRAMES
}

\author{
Ahmed Adel Mostafa, Waleed Abo El Wafa, Khairy Hassan Abd El Kareem \\ Civil Engineering Department, Faculty of Engineering, Assuit University
}

Received 26 August 2018; Accepted 2 October 2018

\begin{abstract}
This paper presents a theoretical finite element study on effect of different strengthening techniques on structural behavior of the reinforced concrete frames subjected to earthquake motion. In the study, diagonal cross bracing, masonry infill wall, externally CFRP laminates, and reinforced concrete jacketing for columns are considered as different strengthening techniques of one story reinforced concrete bare frame. Time history analysis for the frame subjected to EL-Centro (1940 $\mathrm{N}-\mathrm{S}$ ) earthquake ground motion is carried out using ETABS software. The obtained results from the time history analysis including axial and shear stresses, lateral displacement, acceleration and base shear with time are illustrated and discussed with/ or without the strengthening techniques. The study illustrates the influence and enhancement of each technique on the performance of one story bare frame subjected to EL-Centro earthquake motion.
\end{abstract}

Keywords: Seismic behavior, RC one story frame, Nonlinear finite element, Time history analysis, Strengthening techniques, Diagonal cross bracing, Infill wall brick, CFRP laminates, RC jacketing, Acceleration, Lateral displacement, Strength and stiffness, Story Drift.

\section{Introduction}

Many buildings suffered high damages and deficiencies during recent major earthquake such as 1982 earthquake in Yemen, the 1992 Cairo earthquake in Egypt, the 1995 Hyogoken Nanbu earthquake in Japan, 1999 Izmit and Ducze earthquakes in Turkey, the 2001 Bhuj earthquake in India, 2001 Chi Chi earthquake in Taiwan, 2003 Boumerdes earthquake in Algeria, the 2009 Southern Sumatra in Indonesia, and the 2011 Van earthquake in Turkey. These quakes caused catastrophic collapses and a death toll measured in thousands. The main reason for this damages is that most buildings had been designed to resist only vertical loads and had insufficient lateral resistance $[1,11,13,14,15,17]$.

Many of these structures had been designed and constructed before the introduction of adequate seismic design code provisions. In the Arab World, until 1990s, there was no regulation to design and construct building structures for seismic resistance. In Egypt the first official code of practice to consider seismic loading was published by the Ministry of Housing[7,17,22]. Extensive researches have been conducted to develop methodologies to provide additional lateral stiffness to existing buildings. Most commonly used techniques 
are infilling of selected frames, bracing, using of externally CFRP laminates and jacketing of frame members. In this study, these techniques are presented as follow:

a) Strengthening of RC frames by utilizing steel cross bracing.

Diagonal bracing system is one of the retrofitting techniques; it provides an excellent approach for strengthening and stiffening existing building for lateral forces. Moreover, it has many advantages such as simplicity, low cost and the comparatively small increase in mass associated with the retrofitting scheme. Bracing of reinforced concrete frames is usually performed for the purpose of increasing the strength or strength and ductility against earthquake induced force [18] Steel bracing is a highly efficient and economical method of resisting horizontal forces in a frame structure. Bracing has been used to stabilize laterally the majority of the world's tallest building steel structures as well as one of the major retrofit measures. Bracing is efficient because the diagonals work in axial stress and therefore call for minimum member sizes in providing stiffness and strength against horizontal shear. A bracing system improves the seismic performance of the frame by increasing its lateral stiffness and capacity. Through the addition of the bracing system, load could be transferred out of the frame and into the braces, by passing the weak columns while increasing strength. [8]. However, bracing systems have some disadvantages such as; difficulties during the installation and buckling of cross sections steel elements.

b) Strengthening of RC frames by utilizing infill wall masonry.

Reinforced concrete (RC) frame buildings with masonry wall have been widely constructed for commercial, industrial and multi-story residential uses [12]. Masonry infill walls are frequently used as interior partitions and exterior wall in RC frames. In usual, the infill walls are treated as non-structural element and their influences on the structural response are generally ignored. Furthermore, the presence of masonry infill walls has a significant impact on the seismic response of a reinforced concrete frame building, increasing structural strength and stiffness (relative to an open frame). Properly designed infill can increase the overall strength, lateral resistance and energy dissipation of the structure. [6].An infill wall reduces the lateral deflections and bending moments in the frame, thereby decreasing the probability of collapse. Hence, accounting for the infill in the analysis and design leads reducing the overall cost of the structural system. However, masonry infill wall have some disadvantages such as;

- Extreme weather causes degradation of masonry wall surfaces due to frost damage. This type of damage is common with certain types of masonry, though rare with concrete blocks.

- Masonry tends to be heavy and must be built upon a strong foundation, such as reinforced concrete, to avoid setting and cracking.

c) Strengthening of RC frames by utilizing external CFRP laminates.

Externally bonded carbon fiber polymer CFRP laminates has been widely used recently as a retrofitting technique for a reinforced concrete structures. [2, 19].The advantages for using the externally bonded CFRP laminates can be listed as follow:

- Immune to corrosion.

- High strength to weight ratio.

- Ease of handling and fabrication. 
- Minimal effect on geometry of structural members.

- Defined performance properties.

- Increase the bending capacity of concrete elements.

- Enhance the shear capacity of concrete members.

Moreover, the most imperative characteristic of externally bonded CFRP in strengthening applications is the speed and ease of installation. When FRP jackets are used for the confinement of RC columns, in particular, the enhancement in strength and ductility of the columns can be so efficient that FRP jacketing represents one of the major retrofitting techniques for the improvement of their seismic performance. However, CFRP laminates have some disadvantages such as;

- CFRP laminates are highly expensive. Therefore, cannot be used widely as retrofit technique.

- Bonding between concrete surface and CFRP laminates need to be considered.

d) Strengthening of RC frames by utilizing reinforced concrete jacketing.

RC Jacketing of reinforced concrete columns is the most widespread method of columns strengthening. This retrofitting technique is classified as local retrofitting, which it targets the seismic resistance of a member. Concrete jacketing involves adding a new layer of concrete with longitudinal reinforcement and closely spaced ties. [9, 21].The advantages of using RC jacketing are listed below:

- It increases the seismic resistance of the building.

- It increases the ductile behavior and lateral load capability of the building strength and stiffness.

- It increases and improves the column's flexural strength.

- It increases the shear strength and ductility of the columns.

- The durability of the original column is also improved.

However, RC jacketing has some disadvantages such as;

- The increase in the concrete member size obtained after the jacket is constructed and, need to construct a new formwork.

For laterally confined concrete, Khairy Hassan [10] carried out a comprehensive review of various stress-strain relationships for concrete and steel and he developed and verified the following model the model shown in Figs. (1) and (2).

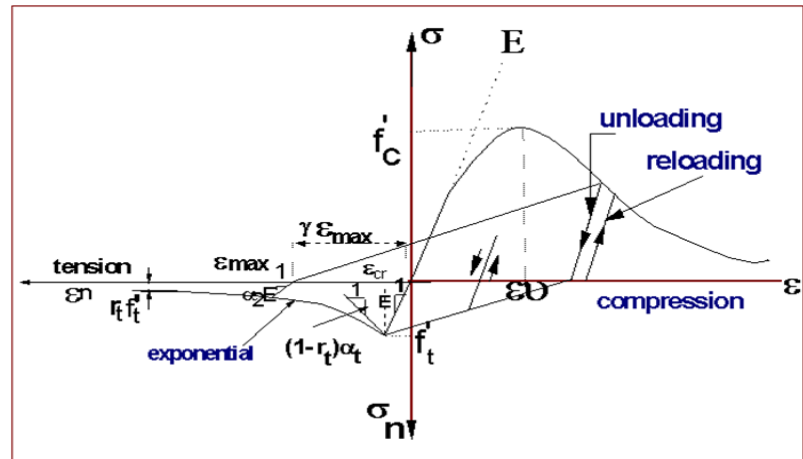

Fig. 1. Stress-Strain curve for Concrete, Khairy Hassan [10]. 


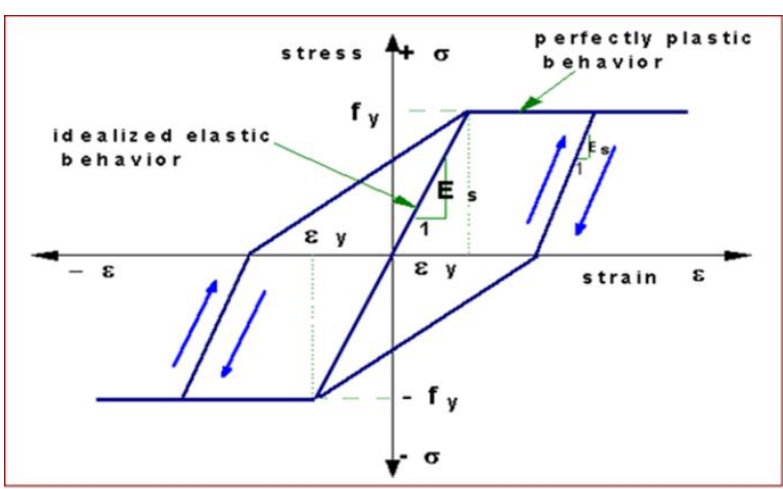

Fig. 2. Stress-Strain curve for Steel, Khairy Hassan [10].

In the paper, four kinds of strengthening techniques are used to demonstrate the efficiency on seismic behavior of RC frame. These techniques are listed as follow;

- Steel cross bracing (SCB).

- Masonry infill wall (MIW).

- External CFRP laminates (ECL).

- RC jacketing (RCJ).

The obtained results are compared and discussed to bare frame model. The previous studies considered on each technique separately of RC frame or steel frame subjected to earthquake motion and listed the results for this technique.

\section{Modeling and cases of study}

In this study, linear time history analysis is carried out for one bay reinforced concrete frame utilizing ETABS analysis software program 2015[3]. The studied case is a one bay reinforced concrete frame. The considered Parameters of study for the bare frame model case and all other cases (frame strengthened by steel cross bracing, infill wall masonry, external CFRP laminates, and RC jacketing) are following:

- Span (L) is equal to $8 \mathrm{~m}$, height $(\mathrm{H})$ is equal to $4 \mathrm{~m}$, hence $\mathrm{L} / \mathrm{H}=2$ is constant for all cases of study.

- Column cross section is (30x80) cm with $10 \Phi 18$ longitudinal reinforcement and

- $5 \Phi 10 / \mathrm{m}^{\prime}$ as stirrups as shown in fig. (3), the column cross section is constant along the height of the frame in all cases of the study.

- Beam cross section is (30x100) cm with $10 \Phi 18$ longitudinal reinforcement in top and bottom of the beam and $5 \Phi 10 / \mathrm{m}$ ' as stirrups as shown in fig. (3). the beam cross section is constant along the span of the frame in all cases of the study.

- The mechanical properties for concrete and steel are illustrated in table (1 and 2), according to Egyptian code of practice (ECP 203-2007). [5]. the materials used are C300 for concrete and St60 for steel (characteristic yield strength for steel of $4000 \mathrm{~kg} / \mathrm{cm} 2$ ). 


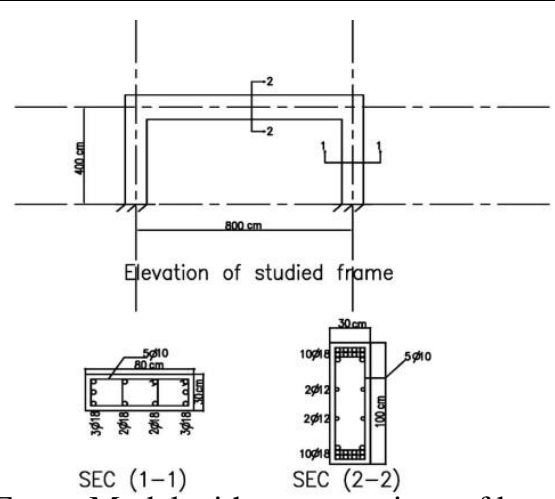

Fig. 3. Frame Model with cross sections of beam \& columns

Table 1.

Mechanical properties for reinforced concrete

\begin{tabular}{|l|l|l|}
\hline & Mechanical property & Reinforced concrete \\
\hline 1 & Density, $\rho\left(\mathrm{kg} / \mathrm{cm}^{3}\right)$ & 0.0025 \\
\hline 2 & Compressive strength, fcu $\left(\mathrm{kg} / \mathrm{cm}^{2}\right)$ & 300 \\
\hline 3 & Modulus of Elasticity, E $\left(\mathrm{kg} / \mathrm{cm}^{2}\right)$ & 240998 \\
\hline 4 & Coefficient of Thermal Expansion, A $(1 / \mathrm{C})$ & 0.0000099 \\
\hline 5 & Shear Modulus, $\mathrm{G}\left(\mathrm{kg} / \mathrm{cm}^{2}\right)$ & 101036 \\
\hline 6 & Poisson ratio, $v$ & 0.2 \\
\hline
\end{tabular}

Table 2.

Mechanical properties for steel (40/60)

\begin{tabular}{|l|l|l|}
\hline & Mechanical property & Steel rebar \\
\hline 1 & Density, $\rho\left(\mathrm{kg} / \mathrm{cm}^{3}\right)$ & 0.0078 \\
\hline 2 & Modulus of Elasticity, E $\left(\mathrm{kg} / \mathrm{cm}^{2}\right)$ & 2100000 \\
\hline 3 & Coefficient of Thermal Expansion, A $(1 / \mathrm{C})$ & 0.0000117 \\
\hline 4 & Yield Strength $(\mathrm{Fy})\left(\mathrm{kg} / \mathrm{cm}^{2}\right)$ & 4000 \\
\hline 5 & Tensile Strength $(\mathrm{Fu})\left(\mathrm{kg} / \mathrm{cm}^{2}\right)$ & 6000 \\
\hline 6 & Poisson ratio, $v$ & 0.3 \\
\hline
\end{tabular}

- Applied loads for all studied models are as follow:

Own weight of the frame calculated by ETABS software program, vertical point loads equal to 10 ton as a live load case, and EL-Centro (1940 N-S) earthquake motion located at base frame as a ground motion, with peak value of $0.319 \mathrm{~g}$ at 2.20 second and total duration of 40 second. The live load and earthquake motion are shown in figs. (4) and (5).

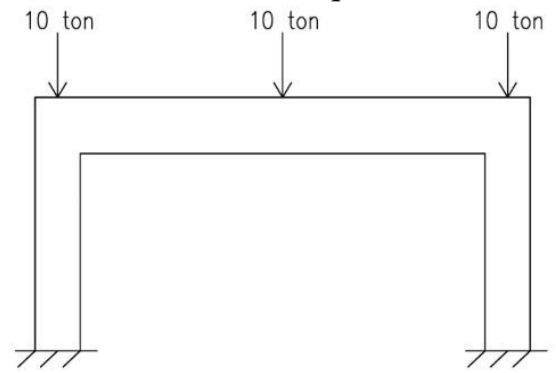

Fig. 4. Frame Model with vertical point loads 


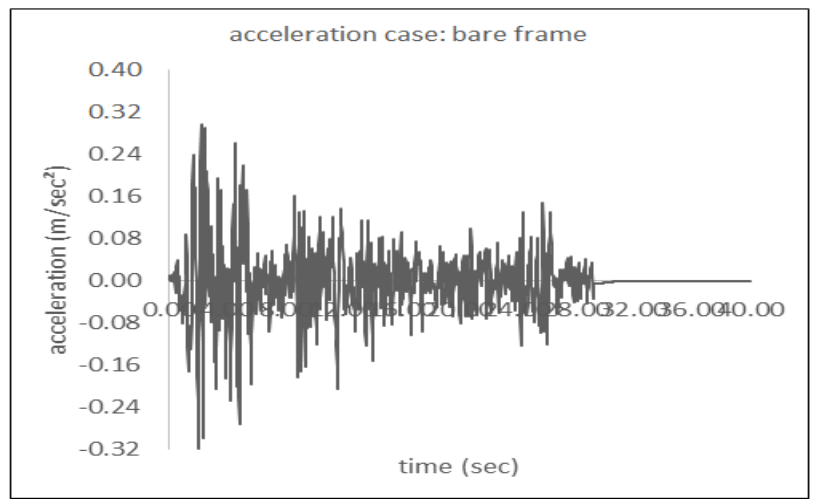

Fig. 5. El Centro (1940 N-S) earthquake motion.

In this study, the strengthening techniques are modeled as follow:

Steel cross bracing (SCB)

The frame is strengthened with SCB. Data of studied model is considered as follow:

- Diagonal bracing section is channel 200 modeled as frame element with pinnedpinned joints in the corners of the frame as shown in fig (6).

- Mechanical properties for steel of diagonal bracing are illustrated in table (3).

- In this study, a complete bond is assumed between diagonal bracing system and concrete surface for the frame.

Stress-strain curve for steel of the diagonal bracing is shown in fig (7), the main parameters used for the stress-strain curve of steel has listed in table (3) and the results obtained by using the ETABS software. The material used is St 37/52 for steel cross bracing, according to American international standard code (AISC 360-10), with the following properties:

Yield strain $\left(\boldsymbol{\epsilon}_{\mathrm{y}}\right)$ is 0.015 for the yield stress $3700 \mathrm{~kg} / \mathrm{cm}^{2}$.

Ultimate strain $\left(\boldsymbol{\epsilon}_{\mathrm{u}}\right)$ is 0.12 for the ultimate strength $5200 \mathrm{~kg} / \mathrm{cm}^{2}$.

Rapture strain $\left(\boldsymbol{\epsilon}_{\mathrm{cr}}\right)$ is 0.2 for the strength in failure mode of $4422 \mathrm{~kg} / \mathrm{cm}^{2}$.

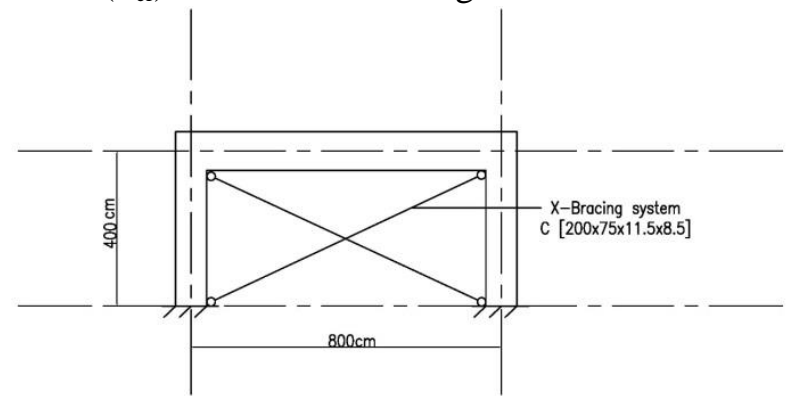

Fig. 6. Frame Model with cross bracing.

Table 3.

Mechanical property for steel of the diagonal bracing.

\begin{tabular}{|l|l|l|}
\hline & Mechanical property & Steel \\
\hline 1 & Density, $\rho\left(\mathrm{kg} / \mathrm{cm}^{3}\right)$ & 0.00785 \\
\hline 2 & Modulus of Elasticity, E $\left(\mathrm{kg} / \mathrm{cm}^{2}\right)$ & 2100000 \\
\hline 3 & Coefficient of Thermal Expansion, A $(1 / \mathrm{C})$ & 0.000012 \\
\hline 4 & Yield Strength $(\mathrm{Fy})\left(\mathrm{kg} / \mathrm{cm}^{2}\right)$ & 3700 \\
\hline 5 & Tensile Strength $(\mathrm{Fu})\left(\mathrm{kg} / \mathrm{cm}^{2}\right)$ & 5200 \\
\hline
\end{tabular}




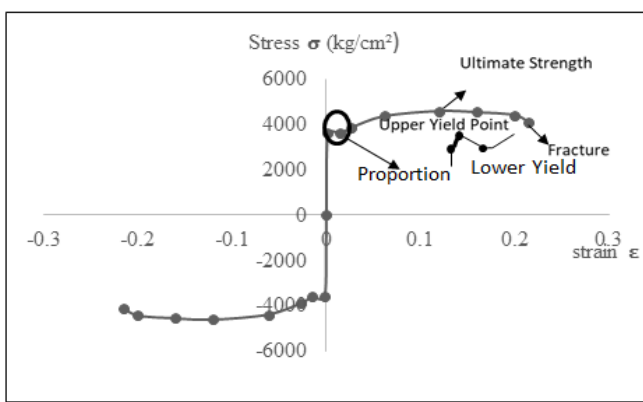

Fig. 7. Stress-Strain curve for steel of the diagonal bracing

Masonry infill wall (MIW)

The frame is strengthened with MIW. Data of model study are considered as follow:

- Masonry thickness of $25 \mathrm{~cm}$ is used for the full infill wall inside the frame, modeled as equivalent diagonal strut with the same material ( brick ) and thickness $(\mathrm{t}$ ) equal $25 \mathrm{~cm}$ same of the infill wall thickness.

- The diagonal strut is modeled as frame element pinned connected to the corners of the $\mathrm{RC}$ frame (hinge joint) as shown in fig. (8) to prevent transfer the bending moments in the diagonal strut from the RC frame. The authors showed the width of the equivalent diagonal strut (we) as shown in fig (8), and the expression of Paulay and Priestley in 1992. [16] was obtained as follows:

$\mathrm{W}_{\mathrm{e}}=0.25 \mathrm{~d}_{\mathrm{m}}(1)$, where $\mathrm{d}_{\mathrm{m}}$ is length of the infill diagonal strut.

$\left.\mathrm{d}_{\mathrm{m}}=\sqrt{\left[(350)^{2}+(720)^{2}\right.}\right]=800 \mathrm{~cm}$. So $\mathrm{W}_{\mathrm{e}}=0.25 \times 800=200 \mathrm{~cm}$.

So the width of the equivalent diagonal strut $\left(\mathrm{w}_{\mathrm{e}}\right)$ is $200 \mathrm{~cm}$ is utilized for the frame element pinned connected to the RC frame. Mechanical properties for infill brick are illustrated in table (4) according to (Dhanasekar 1985). [4].

- Complete bond is assumed between infill brick and concrete surface for the frame.

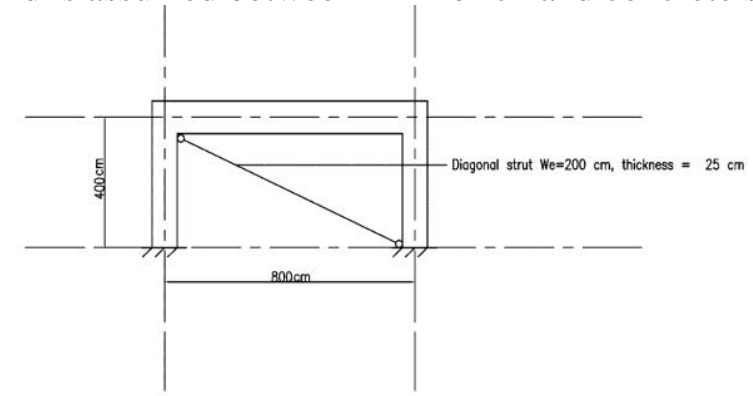

Fig. 8. Frame Model with diagonal strut (infill masonry).

Table 4.

Mechanical property for masonry infill

\begin{tabular}{|l|l|l|}
\hline & Mechanical property & Infill masonry \\
\hline 1 & Density, $\rho\left(\mathrm{kg} / \mathrm{cm}^{3}\right)$ & 0.0016 \\
\hline 2 & Modulus of Elasticity, E $\left(\mathrm{kg} / \mathrm{cm}^{2}\right)$ & 70000 \\
\hline 3 & Coefficient of Thermal Expansion, A $(1 / \mathrm{C})$ & 0.0000081 \\
\hline 4 & Shear Modulus, $\mathrm{G}\left(\mathrm{kg} / \mathrm{cm}^{2}\right)$ & 30434.7 \\
\hline 5 & Compressive strength, $\mathrm{fm}\left(\mathrm{kg} / \mathrm{cm}^{2}\right)$ & 72 \\
\hline
\end{tabular}


External CFRP laminates (ECL)

The frame is strengthened with ECL. Data of model study are considered as follow:

- CFRP laminates thickness is $3 \mathrm{~mm}$, width is $30 / 80 \mathrm{~cm}$ as same width of the column, all sides of the column are wrapped along all height as shown in figs. (9). the selection of the CFRP material should be based on strength, stiffness, and durability required for specific application.

- The CFRP composites are materials that consist of two constituents, which are combined at a macroscopic level and are not soluble in each other. One constituent is the reinforcement, which is embedded in the second constituent, a continuous polymer called the matrix (Kaw 1997). [20].The reinforcing material is in the form of fibers, i.e, carbon which are typically stiffer and stronger than the matrix. The CFRP composites are anisotropic materials that are their properties are not the same in all directions. Poisson ratio has taken 0.22 for CFRP.

- Mechanical properties of CFRP laminates are illustrated in table (5), (according to Sika CarboDur ' $\mathrm{S}$ ' mechanical properties).

- Complete bond is assumed between CFRP laminates and the column side surface.

- Stress-strain curve for CFRP laminates in tension and compression shown in fig (10), the relationship between the stress and strain is obtained by ETABS analysis software program. It is linear and the elastic range given as:

$f_{f}=E_{f} \boldsymbol{\varepsilon}_{f}$

The modulus of elasticity $\left(\mathrm{E}_{f}\right)$ is $1650000 \mathrm{~kg} / \mathrm{cm}^{2}$ and the strain at ultimate stage $\left(\boldsymbol{\varepsilon}_{f}\right)$ is 0.017 from Sika CarboDur ' $S$ ' mechanical properties.

- The ETABS analysis software is used to obtain the results for the frame model strengthened with ECL as shown in fig. (11). Beam and columns are modeled as frame elements defined with the material properties, cross sections, and loads. Columns are modeled with the ECL, Time history analysis is utilized for frame model subjected to earthquake ground motion.

\section{Table 5.}

Mechanical property for CFRP laminates

\begin{tabular}{|l|l|l|}
\hline & Mechanical property & CFRP laminates \\
\hline 1 & Density, $\rho\left(\mathrm{kg} / \mathrm{cm}^{3}\right)$ & 0.0018 \\
\hline 2 & Modulus of Elasticity, E $\left(\mathrm{kg} / \mathrm{cm}^{2}\right)$ & 1650000 \\
\hline 3 & Coefficient of Thermal Expansion, A $(1 / \mathrm{C})$ & 0.00000002 \\
\hline 4 & Tensile Strength $(\mathrm{Fu})\left(\mathrm{kg} / \mathrm{cm}^{2}\right)$ & 28000 \\
\hline
\end{tabular}




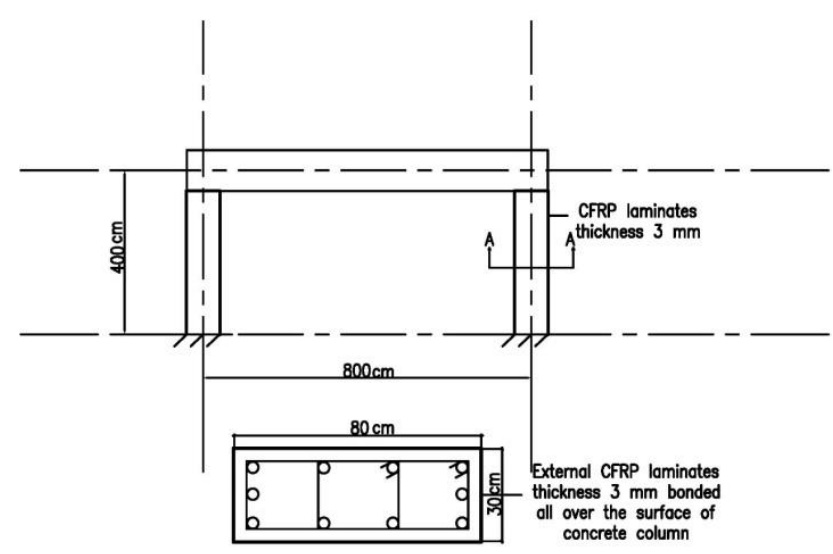

SEC (A-A)

Fig. 9. R.C Frame Strengthening by CFRP Laminates.

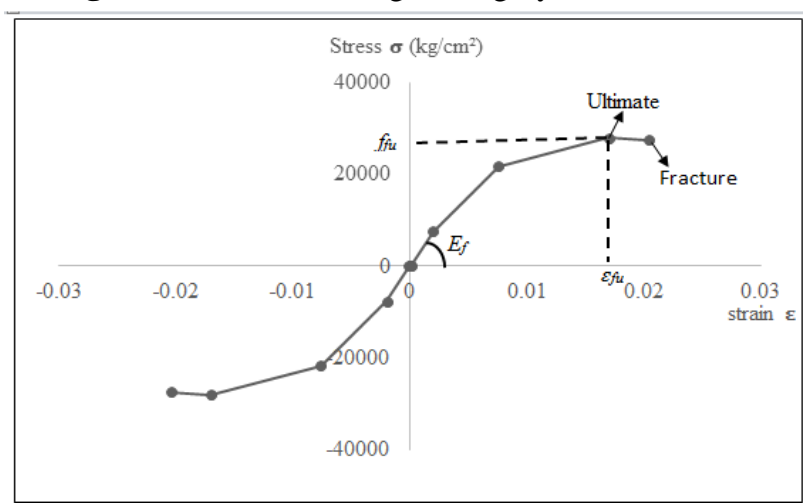

Fig. 10. Stress-Strain curve for CFRP laminates in tension \& compression

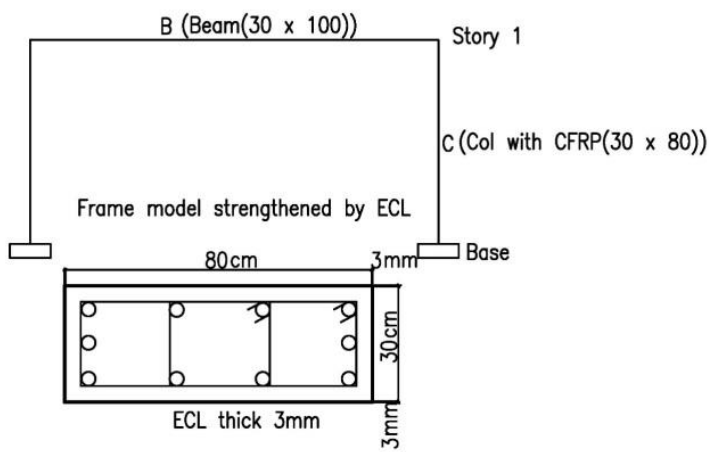

Fig. 11. Frame model strengthened by ECL

RC Jacketing (RCJ)

The frame is strengthened with using RCJ for frame columns as:

Reinforced concrete jacketing dimensions are $15 \mathrm{~cm}$ in breadth and depth above the original dimensions of columns. The new dimensions of the RC jacketing are $60 \mathrm{~cm} \times 110$ cm with $18 \Phi 18$ longitudinal reinforcement rebar and $5 \Phi 10 / \mathrm{m}^{\prime}$ as stirrups. The jacketing is carried out as shown in fig. (12). Mechanical properties for concrete and steel for RC jacketing are illustrated in table $(1,2)$. According to Egyptian code of practice (ECP 2032007). [5]. the materials used are C300 for concrete and St60 for steel (characteristic yield 
strength for steel of $4000 \mathrm{~kg} / \mathrm{cm}^{2}$ ). Complete bond is assumed between the old concrete of the column and new concrete of the RC jacketing.

\section{Analysis and discussion of results}

In this study, finite element is used to analyze RC frames strengthened with different techniques. The analyzed framed included bare frames, frames strengthened by steel cross bracing, frames strengthened by infill brick, frames strengthened by external CFRP laminates, and frames strengthened by RC jacketing. The obtained results illustrated lateral displacement, base shear, and story drift for the studied cases as shown in fig. (13). the purpose is to compare the seismic behavior of frames strengthened with different techniques. The findings of such analysis are summarized as follows

\subsection{Lateral displacement}

The effect of strengthening techniques on reducing the lateral displacement at point 3 for all studied models subjected to El-Centro (1940 N-S) earthquake ground motion is illustrated in table (6).

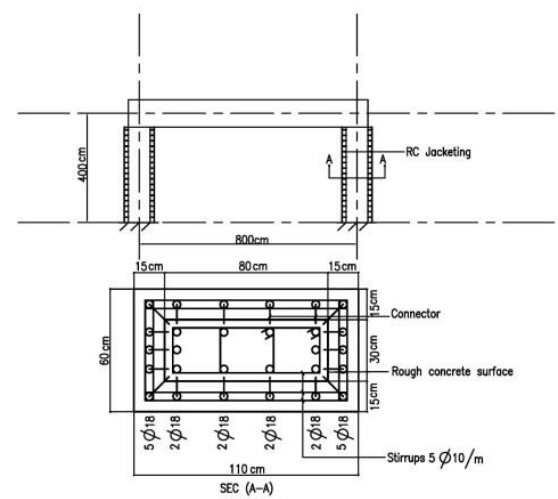

Fig. 12. R.C Frame Strengthening by RC Jacketing

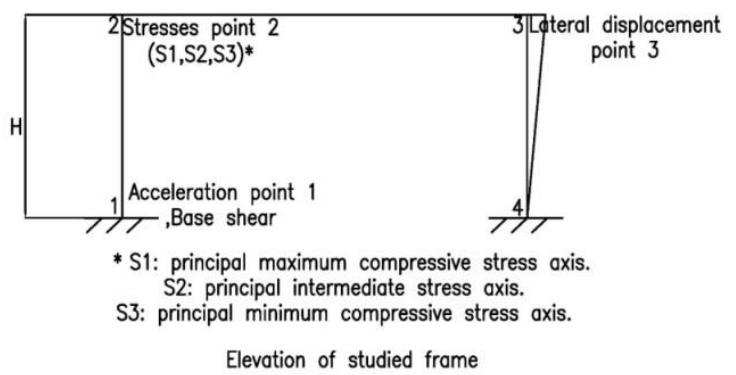

Fig. 13. Frame model with results

Table 6.

Reduction Values for all strengthening techniques

\begin{tabular}{|l|c|l|l|}
\hline Strengthening Technique & Lateral displacement $\Delta \mathrm{mm}$ & $\Delta \Delta \max$ & Reduction $\%$ \\
\hline Bare Frame & 0.03137 & 1.0 & \\
\hline Steel X-Bracing & 0.0125 & 0.398 & 60.2 \\
\hline Infill Masonry & 0.0096 & 0.306 & 69.4 \\
\hline CFRP Laminate & 0.0234 & 0.746 & 25.4 \\
\hline RC Jacketing & 0.0134 & 0.427 & 57.3 \\
\hline
\end{tabular}


The highest value of lateral displacement is $\left(\Delta_{1}\right)=0.03137 \mathrm{~mm}$ was for the bare frame model and the lowest value was $\left(\Delta_{3}\right)=0.0096 \mathrm{~mm}$ for frame strengthened by masonry infill.

Compared to bare frame model, the highest reduction of lateral displacement is $69.4 \%$ and $25.4 \%$ for frame strengthened by infill masonry and CFRP laminates respectively. This means that strengthening with infill masonry gives the highest reduction of lateral displacement equal 2.7 times the reduction of the CFRP laminates, 1.15 times the reduction of the steel x-bracing, and 1.2 times the reduction of the RC jacketing on the RC frame subjected to earthquake ground motion. Consequently, it is recommended to use such technique if reduction of lateral displacement is needed.

\subsection{Base shear}

The effect of strengthening techniques on changing base shear of the frame at point 1 for all studied models subjected to El-Centro (1940 N-S) earthquake ground motion is illustrated in table (7).

Table 7.

Reduction Values for all strengthening techniques

\begin{tabular}{|l|l|l|l|}
\hline $\begin{array}{c}\text { Strengthening } \\
\text { Technique }\end{array}$ & Base Shear (ton) & Base shear /base shear of bare frame & Reduction \% \\
\hline Bare Frame & 0.3726 & 1.0 & \\
\hline Steel X-Bracing & 0.3114 & 0.836 & 16.4 \\
\hline Infill Masonry & 0.551 & 1.479 & -47.9 \\
\hline CFRP Laminates & 0.3814 & 1.02 & -2 \\
\hline RC Jacketing & 0.5446 & 1.46 & -46 \\
\hline
\end{tabular}

The highest value of base shear is 0.551 ton for the frame strengthened by infill masonry, and the lowest value is 0.3114 ton for the frame strengthened by steel x-bracing.

Compared to bare frame, the highest reduction of base shear is $16.4 \%$ for the frame model strengthened by steel x-bracing. Base shear direction was changed and increased to $47.9 \%, 46 \%$ and $2 \%$ respectively for the frame strengthened by masonry infill, RC jacketing, and 2\% CFRP laminates respectively. This means that strengthening with steel $\mathrm{x}$-bracing gives the significant decrease of base shear. Consequently, it is recommended to use such technique if reduction of base shear is needed.

\subsection{Column axial stress}

The effect of strengthening techniques on reducing the column axial stress in all studied models subjected to El-Centro (1940 N-S) earthquake ground motion is illustrated in table (8).

Table 8.

Reduction Values for all strengthening techniques

\begin{tabular}{|l|l|l|l|}
\hline Strengthening Technique & Column Axial Stress $\sigma_{11}\left(\mathrm{t} / \mathrm{m}^{2}\right)$ & $\sigma_{11} / \sigma_{11} \max$ & Reduction \% \\
\hline Bare frame & 9.79 & 1.0 & \\
\hline Steel X-Bracing & 4.15 & 0.424 & 57.6 \\
\hline Infill Masonry & 3.31 & 0.338 & 66.2 \\
\hline CFRP Laminate & 7.32 & 0.748 & 25.2 \\
\hline RC Jacketing & 4.45 & 0.455 & 54.5 \\
\hline
\end{tabular}


The highest value of column axial stress is $\left(\sigma_{11}\right)=9.79 \mathrm{t} / \mathrm{m}^{2}$ for the bare frame model, and the lowest value is $\left(\sigma_{11}\right)=3.31 \mathrm{t} / \mathrm{m}^{2}$ for the frame strengthened by infill masonry.

Compared to bare frame, the highest reduction of column axial stress is $66.2 \%$ and 25.2 $\%$ for the frame strengthened by masonry infill and CFRP laminates respectively. This means that strengthening with infill masonry gives the highest reduction of column axial stress equal 2.6 times the reduction of the CFRP laminates, 1.15 times the reduction of the steel $\mathrm{x}$ - bracing, and 1.2 times the reduction of the $\mathrm{RC}$ jacketing on the $\mathrm{RC}$ frame subjected to earthquake ground motion. Consequently, it is recommended to use such technique if reduction of column axial stress is needed.

\subsection{Column shear stress}

The effect of strengthening techniques on reducing the column shear stress in all studied models subjected to El-Centro $(1940 \mathrm{~N}-\mathrm{S})$ earthquake ground motion is illustrated in table (9).

Table 9.

Reduction Values for all strengthening techniques

\begin{tabular}{|l|l|l|l|}
\hline Strengthening Technique & Column shear stress $\sigma_{12}\left(\mathrm{t} / \mathrm{m}^{2}\right)$ & $\sigma_{12} / \sigma_{12} \max$ & Reduction \% \\
\hline Bare Frame & 0.86 & 1.0 & \\
\hline Steel X-Bracing & 0.35 & 0.407 & 59.3 \\
\hline Infill Masonry & 0.23 & 0.267 & 73.3 \\
\hline CFRP Laminate & 0.0002 & 0.0002 & 99.98 \\
\hline RC Jacketing & 0.00045 & 0.0005 & 99.95 \\
\hline
\end{tabular}

The highest value of column shear stress is $\left(\sigma_{12}\right)=0.86 \mathrm{t} / \mathrm{m}^{2}$ for the bare frame model, and the lowest value is $\left(\sigma_{12}\right)=0.00023$ and 0.00052 for the frame strengthened by CFRP laminates and $\mathrm{RC}$ jacketing respectively.

Compared to bare frame, the highest reduction of column shear stress is $99.98 \%, 99.95$ and $59.3 \%$ for the frame strengthened by CFRP laminates, RC jacketing and steel xbracing respectively. The influence of utilizing the CFRP Laminates and R.C Jacketing to wrap and retrofit all sides of column for one story model frame is enhanced effectively the shear strength of the RC columns, equal 1.7 times the reduction of the steel $\mathrm{x}$ - bracing, and 1.4 times the reduction of the infill masonry on the RC frame subjected to earthquake ground motion. Consequently, it is recommended to use such technique if reduction of column shear stress is needed.

\section{Summary and conclusions}

In this research, linear time history analyses is performed for a one bay RC frame, subjected to EL-Centro earthquake ground motion. Steel $\mathrm{x}$ - bracing, masonry infill, external CFRP laminates, RC jacketing were used to strengthen the frame. The steel $\mathrm{x}-$ bracing was modeled as frame element with pinned-pinned joints in the corners of the frame, masonry infill was modeled as equivalent diagonal strut. External CFRP laminates wrapped all sides of the columns frame. RC jacketing covered the columns of frame. Seismic behaviors of RC frame with and without strengthening techniques were investigated. Finally, the main findings of the study can be summarized as follow;

- When using masonry infill as strengthening technique, it can affect the seismic behavior of frame structure to large extent, the masonry infill increases the strength and stiffness of the frame. As a result, there is a significant decrease in lateral 
displacement and column axial stress. The lateral displacement is reduced to $69.4 \%$ compared to bare frame. The column axial stress is reduced to $66.2 \%$ compared to bare frame.

- When using steel x-bracing as strengthening technique, it improves the seismic performance of the frame by increasing its lateral stiffness and capacity. Moreover, the steel $x$-bracing increases the strength and ductility against earthquake induced force. As a result, there is a significant decrease in base shear. The base shear is reduced to $16.4 \%$ compared to bare frame.

- When using external CFRP laminates and RC jacketing for columns as strengthening techniques external, the CFRP laminates enhances the strength and ductility of the columns and improves their seismic performance. RC jacketing increases and improves the column's shear strength and ductility. So, the seismic resistance of the frame is increased. As a result, there is a significant decrease in shear stress. The ratio of column shear stress to column shear stress max $(\sigma 12 / \sigma 12$ $\max$ ) is 0.0002 and 0.0005 for the frame strengthened by CFRP laminates and RC jacketing respectively. So, the shear stress is reduced to $99.98 \%(100 \%-0.02 \%)$ and $99.95 \%(100 \%-0.05 \%)$ compared to bare frame.

- Finally, the choice of the strengthening technique depends on the purpose of the strengthening as it is illustrated within the research:

- Strengthening with infill masonry gives the highest reduction of lateral displacement. Consequently, it is recommended to use such technique if reduction of lateral displacement is needed.

- X-bracing is preferred if high reduction of base shear is required by designer and the induced axial normal stress of column

- The utilizing the CFRP Laminates and R.C Jacketing to wrap and strengthen all sides of column has effective influence on shear strength of the RC columns, and ductility.

\section{REFERENCES}

[1] A. Awad, H. Bassam, and I. Talal, "Moment Resisting Frame Designed for Gravity Loads Only," World Housing Encyclopedia, an initiative of Earthquake Engineering Research Institute (EERI) and International Association for Earthquake Engineering (IAEE). 2002.

[2] Balsamo A., Colombo A., Manfredi G., Negro P. and Prota A.; Seismic behavior of a fullscale RC frame repaired using CFRP laminates. Eng. Struct. 27, 769-780. 2005.

[3] Computers and Structures, Inc (CSI), ETABS 2015 university Avenue Manuals, Berkeley, California. (1998).

[4] Dhanasekar. The performance of brick masonry subjected to in plane loading. Dissertation No. 990. Newcastle: University of Newcastle, Australia, M. 1985.

[5] Egyptian code for Design and Construction the Reinforced Concrete Building (ECP 203-2007), 2007.

[6] Euro code 8: Design of structures for earthquake resistance - Part 3: Assessment and retrofitting of buildings. EN 1998-3, CEN, Brussels; 2005.

[7] Hatzigeorgiou, G. and Liolios, Ast. (2010). Nonlinear behavior of RC frames under repeated strong ground motions. Soil Dynamics and Earthquake Engineering, vol. 30, 1010-1025, 2010.

[8] Japan Building Disaster Prevention Association (JBDPA). English Version: Standard for Seismic Evaluation of Existing Reinforced Concrete Buildings, Guidelines for Seismic Retrofit of Existing Reinforced Concrete Buildings, and Technical Manual for Seismic Evaluation and Seismic Retrofit of Existing Reinforced Concrete Buildings. Tokyo, Japan, 2005.

[9] Julio, E.S., F. Branco and V.D. Silva. Structural rehabilitation of columns using reinforced concrete jacketing. Prog. Struct. Eng. Mater. 5: 29-37. 2003. 
[10] Khairy Hassan Abdelkareem, "Analytical Study on Seismic Resistant Characteristics of RC Bridge Piers,” Thesis Submitted for PHD. Eng. Degree, Saitama University, Japan, 1999.

[11] M. A. Al-masni, "Earthquake Building Risk Assessment in Sana'a City, Yemen," Final Report, Asian Disaster Reduction Center, 2012.

[12] Matjaz D., Fajfar P. Simplified Non-linear Seismic Analysis of Infilled Reinforced Concrete Frames. Earthquake Engineering and Structural Dynamics 34:1, 49-66. (2005).

[13] M. Galli, "Evaluation of the Seismic Response Of Existing R.C. Frame Buildings With Masonry Infills," PhD Thesis, University of Pavia, Italy, 2006.

[14] Murty, Brzev, H. Faison, Comartin, and A. Irfanoglu, AT RISK: The Seismic Performance of Reinforced Concrete Frame Buildings with Masonry Infill Walls. Earthquake Engineering Research Institute, Oakland, California, 2006.

[15] Ö. Çavdar and A. Bayraktar, "Pushover and Nonlinear Time History Analysis Evaluation of a RC Building Collapsed During the Van (Turkey) Earthquake on October 23, 2011," Natural Hazards, [Online]. Available: http://link.springer.com/10.1007/s11069-013-0835-3. 05-Sep-2013.

[16] Paulay and Priestley, Seismic Design of Reinforced Concrete and Masonry Buildings. New York: Jhon Wiley 1992.

[17] S. E. Abdel Raheem, "Evaluation of Egyptian Code Provisions for Seismic Design of Moment-Resisting-Frame Multi-Story Buildings," International Journal of Advanced Structural Eng., vol. 5, no. 3, 2013.

[18] Tasnimi, A.A. and Massumi, A. Strengthening of Reinforced Concrete Frames by Steel Bracings, Building and Housing Research Center (BHRC), Publication No.: R-331, Tehran, Iran. (2000).

[19] Teng J.G -Chen J.F. -.Smith S.T - L. lam- 2002 "FRP Strengthened RC Structures" .Published by Wiley "ACI 440.2R- Guide for Design and Construction of Externally Bonded FRP Systems for Strengthening Concrete Structures" - Reported by ACI committee. 2002.

[20] Thomas J."FRP strengthening - Experimental or mainstream technology", Concrete International, ACI, 1998, pp57-58. 1998

[21] V andoros, K.G. and S.E. Dritsos. Concrete jacket construction detail effectiveness when strengthening RC columns. Construct. Build. Mater.22: 264-276. 2008.

[22] V. Pascucci, M. W. Free, and Z. A. Lubkowski, "Seismic Hazard and Seismic Design Requirements for the Arabian Peninsula Region," in The 14th World Conference on Earthquake Engineering, China. October 2008. 


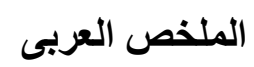

فى هذا البحث تم استخدام نظرية العناصر المحددة الخطية لدر اسة كفاءة اساليب التقوية للإطار الخرسـاني

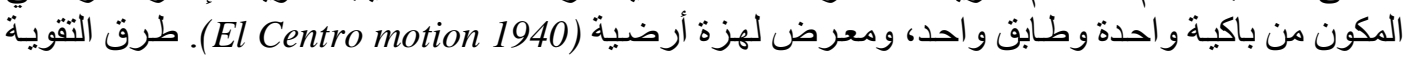

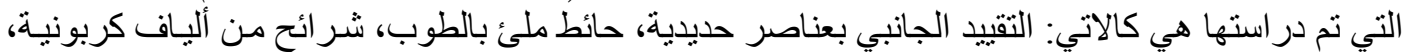

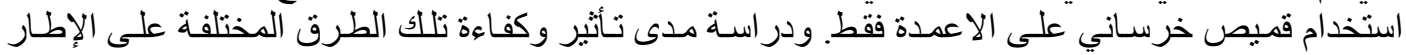

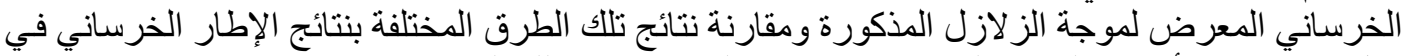

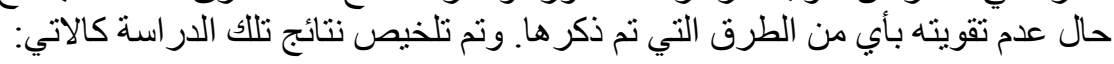
ـ ـ في حال استخدام الحائط المليء بالطوب للإطار الخرسـاني حدث انخفاض بالإز احسة الجانبية مقدار ها

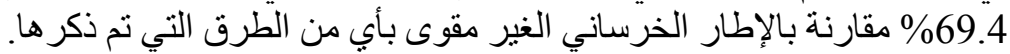

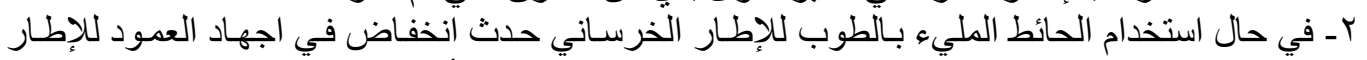

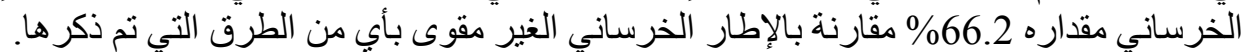

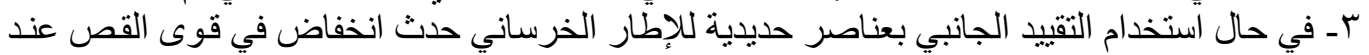

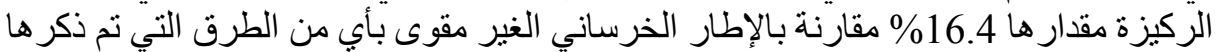

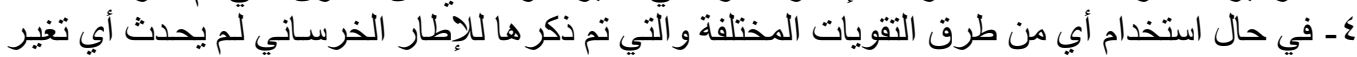

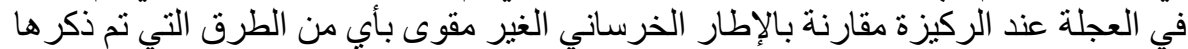

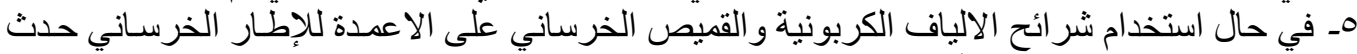

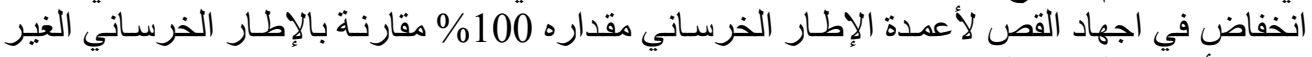

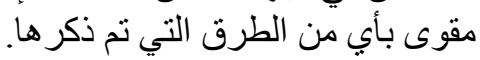
7ـ ان اختبار طريقة التقوية يعتمد على الهدف كما تم توضيحه في البحث 